\title{
REVIEW
}

\section{Protein tyrosine phosphatases and signalling}

\author{
Andrew W Stoker \\ Institute of Child Health, University College London, 30 Guilford Street, London WC1N 1EH, UK \\ (Requests for offprints should be addressed to A W Stoker; Email: astoker@ich.ucl.ac.uk)
}

\begin{abstract}
A cornerstone of many cell-signalling events rests on reversible phosphorylation of tyrosine residues on proteins. The reversibility relies on the co-ordinated actions of protein tyrosine kinases and protein tyrosine phosphatases (PTPs), both of which exist as large protein families. This review focuses on the rapidly evolving field of the PTPs. We now know that rather than simply scavenging phosphotyrosine, the PTPs specifically regulate a wide range of signalling pathways. To illustrate this and to highlight current areas of agreement and contention in the
\end{abstract}

field, this review will present our understanding of PTP action in selected areas and will present current knowledge surrounding the regulatory mechanisms that control PTP enzymes themselves. It will be seen that PTPs control diverse processes such as focal adhesion dynamics, cell-cell adhesion and insulin signalling, and their own actions are in turn regulated by dimerisation, phosphorylation and reversible oxidation.

Journal of Endocrinology (2005) 185, 19-33

\section{Introduction}

The development and physiology of multicellular organisms rely heavily on dynamic interactions between hundreds of cell types in the body. Cell-cell communication through biochemical signalling underpins this multicellularity and we are learning an ever-increasing amount about the molecules and processes involved. One cornerstone of intracellular signalling rests on the ability of proteins to be reversibly phosphorylated by protein kinases and protein phosphatases. Such phosphorylation alters target proteins by inducing conformational changes, creating docking sites for other proteins and causing intracellular relocation. Phosphotyrosine, which makes up around $0 \cdot 1 \%$ of the total cellular phosphoamino acid content, plays a disproportionate part in cell signalling. Protein tyrosine phosphorylation is regulated by protein tyrosine kinases (PTKs) and protein tyrosine phosphatases (PTPs) and this review will concentrate on the latter. The function of PTPs is not simply to scavenge phosphotyrosine and to 'reset the clock'. Instead, the past decade has uncovered a wide range of signalling pathways that are regulated by PTPs as will be illustrated and discussed below.

\section{The PTP family}

PTPs fall into four classes: the classical receptor PTPs (RPTPs), the classical non-receptor PTP (nrPTPs), the dual specificity PTP (dsPTPs) and the low $M_{\mathrm{r}}$ PTPs (Alonso et al. 2004). Only RPTPs and nrPTPs will be discussed here and readers are encouraged to refer to additional, recent reviews on the enzyme family (Fauman \& Saper 1996, Ramponi \& Stefani 1997, Beltran \& Bixby 2003, Johnson \& Van Vactor 2003, Paul \& Lombroso 2003). RPTPs and nrPTPs fall into several subtypes based on their non-catalytic domain structures (examples in Fig. 1) (Paul \& Lombroso 2003). RPTPs are predominantly found in the plasma membrane, whereas nrPTPs are localised to a variety of intracellular compartments, including the cytosol, plasma membrane and endoplasmic reticulum. The catalytic targets of most PTPs were largely unclear until recently, as were the extracellular ligands of most RPTPs. Nevertheless, this has gradually been changing and recent years have seen important advances in our knowledge surrounding PTP regulation and signalling.

\section{Roles in signalling}

To illustrate our current state of understanding, as well as its deficiencies, this review will examine three topical areas of PTP function, (a) cell-substrate adhesion, (b) cell-cell adhesion and (c) insulin signalling. Interested readers are encouraged to read other excellent reviews that cover additional areas of PTP signalling as well as their cellular and developmental functions (Espanel et al. 2001, Stoker 2001, Beltran \& Bixby 2003, Johnson \& Van Vactor 2003, 


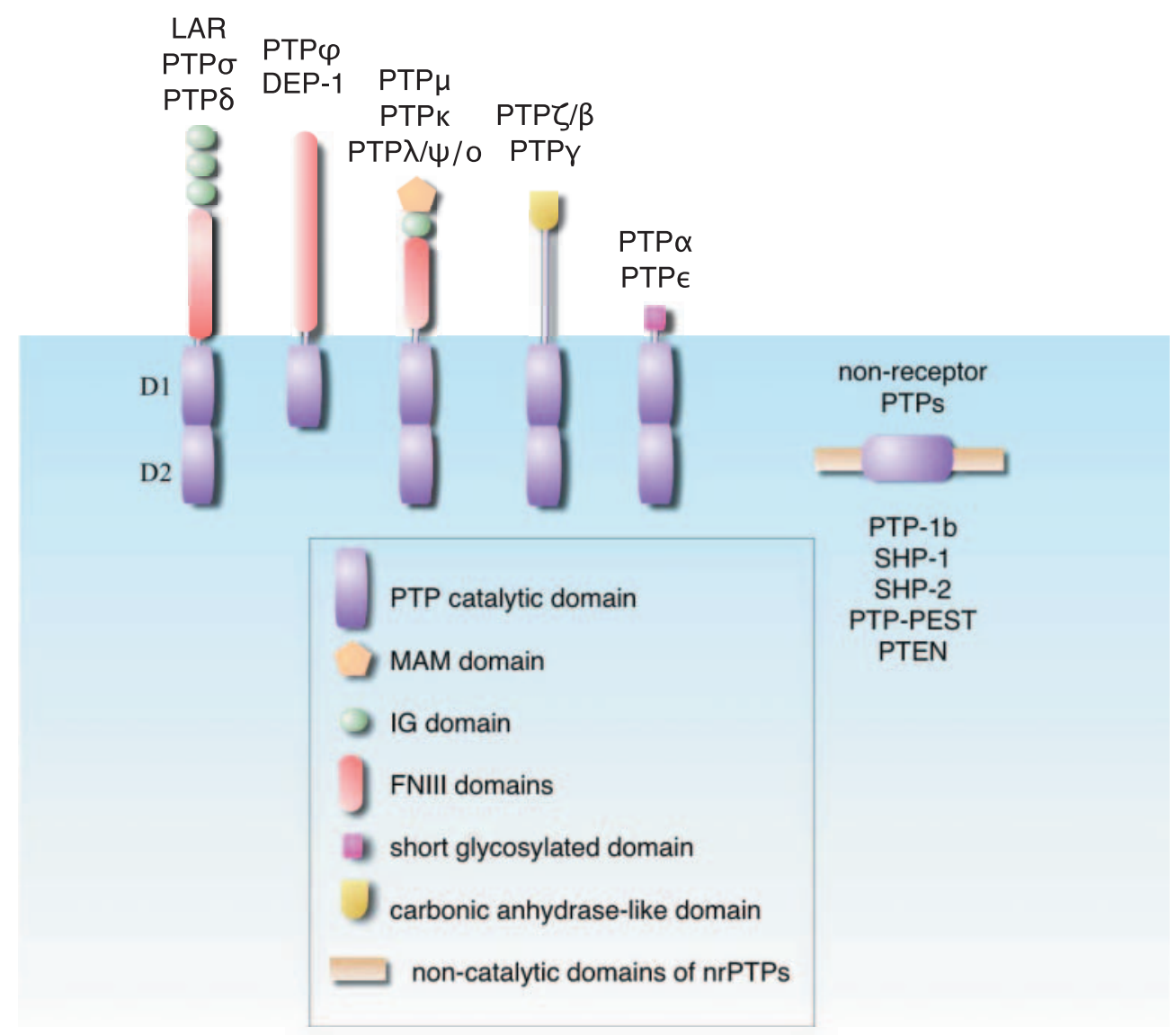

Figure 1 Schematic of the PTP family. The structures of RPTPs discussed in this review are shown: LAR, PTP $\sigma$, PTP $\delta$ (type Ila); PTP $\mu$, PTPк, PTP $\lambda / \psi / O$ (type Ilb); PTP $\varphi$, DEP-1 (type III); PTP $\alpha$, PTP $\varepsilon$ (type IV); $\mathrm{PTP} \zeta / \beta, \mathrm{PTP} \gamma$ (type V). All but class III have duplicated catalytic domains D1 and D2. Each subclass has unique extracellular domain structures depicted by coloured symbols as indicated. The cytoplasmic PTPS only have single PTP catalytic domains, and their additional domain structures are discussed elsewhere. For further references, see 'The PTP family' in the text. IG, immunoglobulin-like domain; FNIII, fibronectin type III domain; MAM, meprin/A5-protein/PTPmu.

Paul \& Lombroso 2003, Ensslen-Craig \& Brady-Kalnay 2004).

\section{Substrate adhesion and motility}

Interactions between cells and the extracellular matrix are essential for the maintenance of cell differentiation, survival and motility. These interactions are governed largely by integrins, heterodimeric transmembrane protein complexes that can bind multiple extracellular molecules and can nucleate adhesive structures known as focal adhesions (FAs) (Schwartz 2001, Zamir \& Geiger 2001, Miranti \& Brugge 2002, Parsons 2003). Integrin binding leads to autophosphorylation of focal adhesion kinase (FAK), activation of the pp $60^{\mathrm{src}} \mathrm{PTK}$ and then a cascade of downstream tyrosine phosphorylations (Fig. 2A) (Schaller et al. 1994). For a cell to de-attach and migrate, the phosphorylation of focal adhesion components must be revers- ible (Schwarzbauer 1997) and this is the job of the PTPs. Several of these enzymes have now been implicated in the regulation of cell adhesion and FA dynamics (AngersLoustau et al. 1999a, Beltran \& Bixby 2003, Larsen et al. 2003) (Fig. 2A).

PTP-PEST PTP-PEST is a widely expressed nrPTP with interaction domains rich in proline, glutamic acid, serine and threonine (Garton \& Tonks 1994). PTP-PEST binds directly to $\mathrm{p} 130^{\text {cas }}$ (Garton et al. 1997), Grb2 (Charest et al. 1997), Csk (Davidson et al. 1997), Shc (Davidson \& Veillette 2001) and paxillin (Shen et al. 1998). The roles of these interactions are largely unclear, but the dephosphorylation of $\mathrm{p} 130^{\mathrm{cas}}$ may be central to PTP-PEST's actions. Overexpression of PTP-PEST in fibroblasts induces $\mathrm{p} 130^{\mathrm{cas}}$ hypophosphorylation, hindering the translocation of $\mathrm{p} 130^{\text {cas }}$ to membrane ruffles, and reducing cell migration (Garton \& Tonks 1999). 
PTP-PEST-deficient fibroblasts also exhibit increased numbers of focal adhesions, increased phosphorylation of p130 ${ }^{\text {cas }}$, paxillin and FAK, and defects in cell motility (Angers-Loustau et al. 1999b). PTP-PEST therefore appears to regulate FA turnover, such that either over- or underexpression of PTP-PEST can cause an imbalance resulting in impaired motility.

PTP1B Evidence for the involvement of PTP1B in integrin signalling, FA formation and cell motility provides a complex, contradictory picture. Knock-down of PTP1B expression using antisense oligonucleotides (Hassid et al. 1999) or overexpression of wild-type PTP1B (Liu et al. 1998) both suggest correlations between PTP1B activity and decreased adhesion, motility and FA formation. PTP1B may negatively regulate adhesion-based signalling by directly dephosphorylating p130 ${ }^{\text {cas }}$ (Fig. 2A). However, other studies using dominant-negative PTP1B (Arregui et al. 1998) and PTP1B-deficient fibroblasts (Cheng et al. 2001) both support the opposite view that PTP1B activates $\mathrm{pp} 60^{\mathrm{src}}$ (or fyn) directly or indirectly, thereby stimulating FAK and $\mathrm{p} 130^{\mathrm{cas}}$ phosphorylation and FA formation. Until we can clarify whether, in different cell types and under different conditions, PTP1B does indeed have divergent effects, the contradictions in these data will remain.

RPTP $\boldsymbol{\alpha}$ pp $60^{\text {src }}$-like PTKs heavily influence FA dynamics (Parsons 2003). pp60 ${ }^{\text {src }}$ is regulated by a carboxyterminal, inhibitory tyrosine (Schwartzberg 1998), the phosphorylation of which is reciprocally controlled by the Csk PTK and PTPs such as RPTPa (Harder et al. 1998). $\mathrm{PTP} \alpha$ overexpression in A431 cells causes increased pp60 $0^{\text {src }}$ activity and pp60 $60^{\text {src }} /$ FAK association (Harder et al. 1998). The opposite seems to occur in RPTP $\alpha$-deficient cells (Su et al. 1999, Zeng et al. 2003). By acting as a pp $60^{\text {src }}$ activator, RPTP $\alpha$ is thus uniquely situated to act upstream of FAK in integrin signalling. PTP $\alpha$ can also target $\mathrm{p} 130^{\mathrm{cas}}$ as a direct substrate in cultured cells (Buist et al. 2000). One puzzle with RPTPa is how, or indeed if, it is regulated by external cues, upstream of any effects on FAs. This must await the identification of an extracellular ligand.

SHP-2 SHP-2 is an ubiquitous enzyme implicated in both growth factor receptor signalling and integrin signalling (Feng 1999, Neel et al. 2003). The mechanism of SHP-2 action remains controversial, though, and the critical downstream targets are largely unclear (Neel et al. 2003). SHP-2 is an nrPTP with two integral SH2 domains that bind to phosphotyrosine residues in receptors and docking proteins (see also 'Regulation of PTP action' below) (Neel et al. 2003). Several studies point to SHP-2 being either a positive or a negative regulator of cell adhesion and motility. One model suggests that integrin engagement causes pp $60^{\mathrm{src}}$-dependent phosphorylation of membrane-bound SHPS-1 (SHP substrate 1), which in turn recruits SHP-2. SHP-2 may then further activate pp60 ${ }^{\text {src }}$, possibly via inhibition of Csk (Zhang et al. 2004), leading to increased FAK phosphorylation (Fig. 2A). To support this, SHP-2-deficient fibroblasts exhibit FAK and pp60 ${ }^{\text {src }}$ hypophosphorylation (Oh et al. 1999). Other studies, however, show that SHP-2 either triggers FAK hypophosphorylation or has little effect (Tsuda et al. 1998, Yu et al. 1998, Manes et al. 1999, Inagaki et al. 2000). SHP-2 is also implicated in the repulsive guidance of cell migration triggered by Eph receptor tyrosine kinases (RTKs), which bind to FAK constitutively. This repulsion is regulated in part by preventing integrin-mediated adhesion (Miao et al. 2000, Poliakov et al. 2004). Upon EphA2 activation by ephrins, SHP-2 binds to EphA2, leading to a loss of FAK and paxillin phosphorylation; EphA2-FAK complexes also break down. Here again, SHP-2 may be a negative regulator of FAK phosphorylation and integrin signalling. Therefore, although the precise mode of action of SHP-2 remains to be clarified, and indeed it may vary between cell types, there is no doubt that SHP-2 can influence FAK activity, cell adhesion and motility.

PTEN PTEN is a tumour suppressor and an unusual enzyme in being able to dephosphorylate both the lipid phosphatidylinositol 3,4,5-triphosphate and phosphotyrosine (Yamada \& Araki 2001). PTEN is implicated in many cellular processes, including cell adhesion, migration, invasion and anoikis (Yamada \& Araki 2001), the latter being apoptosis of cells after loss of matrix contact (Grossmann 2002). Overexpression of PTEN in cells causes hypophosphorylation of FAK and $\mathrm{p} 130^{\mathrm{cas}}$ and reduces cell motility (Tamura et al. 1998, 1999a,c). Furthermore, dominant-negative PTEN causes FAK hyperphosporylation and can co-purify FAK (Tamura et al. 1998, 1999c). PTEN also targets the adaptor Shc, which binds to integrin complexes and in turn affects Erk MAP kinase signalling ( $\mathrm{Gu}$ et al. 1998). There are still doubts over PTEN's level of influence over FAK in vivo, however, since PTEN ${ }^{-/-}$cells show no alteration in FAK phosphorylation even though motility is increased (Sun et al. 1999, Liliental et al. 2000). Perhaps PTP-PEST and SHP-2 share the majority of control over FAK and $\mathrm{p} 130^{\text {cas }}$ phosphorylation, while PTEN has a minor, or a very context-specific role. PTEN also appears to promote cell death through anoikis, by hydrolysing phosphatidylinositol 3,4,5-triphosphate $\left(\mathrm{PIP}_{3}\right)$ and inactivating the AKT/PKB pathway. By also dampening FAK and phosphatidylinositol 3-kinase (PI3)-kinase activities, PTEN may therefore accelerate this apoptosis pathway (Tamura et al. 1999b, Yamada \& Araki 2001).

LAR LAR is an adhesion molecule-like RPTP that localises to FAs (Streuli et al. 1988, Serra Pages et al. 1995). LAR binds to liprins, which are enriched at these sites of 


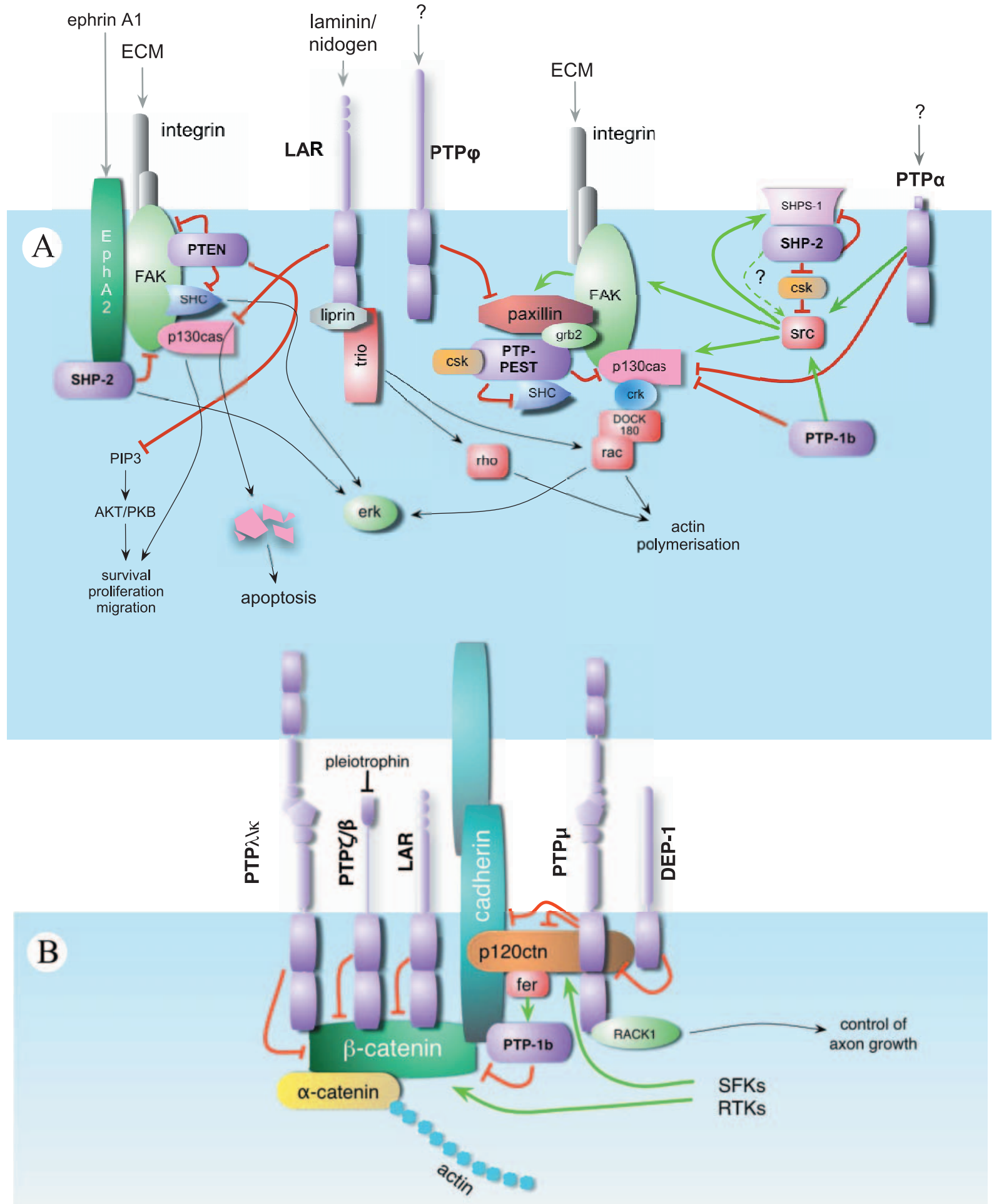


adhesion (Serra-Pages et al. 1998), and to Trio, a large Rac/Rho GTPase that influences the actin cytoskeleton (Debant et al. 1996). An important role for LAR in FAs may revolve around $\mathrm{p} 130^{\text {cas }}$. Overexpression of LAR in U2OS cells causes apoptosis and p130 ${ }^{\text {cas }}$ degradation (Weng et al. 1998, 1999). Anoikis can be triggered by proteolytic fragments of $\mathrm{p} 130^{\text {cas }}$ (O'Neill et al. 2000, Wei et al. 2004) and proteolysis of $\mathrm{p} 130^{\text {cas }}$ can be initiated by hypophosphorylation, induced either by tyrosine kinase inhibition (Wei et al. 2002) or, in all likelihood, by increased PTP activity. Indeed, LAR specifically targets $\mathrm{p} 130^{\mathrm{cas}}$ for dephosphorylation, which may in turn lead directly to its degradation (Weng et al. 1999). Reintroduction of excess $\mathrm{p} 130^{\mathrm{cas}}$ into LAR-expressing cells can partially rescue apoptosis. Interestingly, LAR-induced apoptosis is relatively direct and does not require prior loss of substrate adhesion (Weng et al. 1998). One isoform of LAR is known to bind to laminin (O'Grady et al. 1998) and this PTP may therefore respond directly to the ECM at FAs. The effect of laminin binding on the biochemical activity of LAR remains unclear.

$\mathbf{P T P} \boldsymbol{\varphi}$ PTP $\varphi$ is a type III RPTP, also known as GLEPP1 (Pixley et al. 1995). Studies in macrophages show that paxillin is a $Р$ PР $\varphi$ substrate, and $\operatorname{PTP} \varphi$ co-localises with paxillin in membrane ruffles. Overexpression of $Р$ ТР $\varphi$ in BAC1.2F5 macrophages causes enhanced motility, possibly by reducing the quantity of phosphorylated paxillin available for focal adhesions and increasing FA turnover (Pixley et al. 2001).

While we probably know most of the central PTP players in integrin and FA signalling, there remain many interesting questions. For example, which PTPs are the most influential for focal adhesion dynamics and do different PTPs act in strict concert or are their actions more cell type specific? Put another way, do the conflicting experimental data with individual PTPs reflect genuine, cell-specific differences in enzyme action, or confusion arising from the wide range of under- and overexpression systems and cell types used? Either way, it is clear that a range of cytoplasmic and receptor-type PTPs are involved at several key levels in integrin signalling.

\section{Cell-cell adhesion}

Cell-cell adhesion within epithelia is largely controlled by the cadherin family of homophilic, calcium-dependent adhesion molecules (Daniel \& Reynolds 1997). Their regulated adhesive properties are critical for many morphogenic events including epithelial to mesenchymal transitions (Nakagawa \& Takeichi 1998, Lilien et al. 2002), while defects in cadherin function are also linked to cancer progression (Hirohashi 1998). Understanding how cadherin-based adhesion is regulated is therefore of great importance in the fields of development and disease.

Cadherins are linked to the actin cytoskeleton by $\alpha$-catenin, $\beta$-catenin and $\mathrm{p} 120^{\mathrm{ctn}}$ (Daniel \& Reynolds 1997) (Fig. 2B). The adhesive functions of cadherins are particularly sensitive to tyrosine phosphorylation of $\beta$-catenin. Phosphorylation of $\beta$-catenin causes its dissociation from cadherin and loss of cell-cell adhesion complexes (Balsamo et al. 1996, 1998, Roura et al. 1999). p120 12 may stabilise cadherins at the plasma membrane (Peifer \& Yap 2003, Kowalczyk \& Reynolds 2004) and its tyrosine phosphorylation causes loss of cadherin function (Ozawa \& Ohkubo 2001). Since tyrosine phosphorylation is central to cadherin/catenin function, it is not surprising that PTPs are again found in the arena (Beltran \& Bixby 2003) (Fig. 2B). РTP $\mu$ interacts with cadherin and may be able to dephosphorylate it directly (Brady Kalnay et al. 1995, Brady-Kalnay et al. 1998), although this remains a little controversial (Zondag et al. 1996). PTP1B binds directly to cadherin, but in this case its target is $\beta$-catenin (Fig. 2B). A dominant-negative form of PTP1B causes hyperphosphorylation of $\beta$-catenin and loss of cadherin function, possibly by displacing the wild-type enzyme (Balsamo et al. 1996, 1998, Pathre et al. 2001). PTP1B itself is activated by tyrosine phosphorylation on tyrosine residue 152, catalysed by the PTK Fer (Xu et al. 2004); Fer binds $\mathrm{p} 120^{\mathrm{ctn}}$, thereby holding it near to PTP1B. The $\mathrm{p} 120^{\mathrm{ctn}}$ protein can be dephosphorylated by $\mathrm{PTP} \mu$ and this has been proposed to be a route by which this RPTP controls $\mathrm{N}$-cadherin function in axons (Zondag et al. 2000). DEP-1, a type III RPTP, and the nrPTP SHP-1 can also target $\mathrm{p} 120^{\mathrm{ctn}}$ as a potential substrate (Keilhack et al. 2000, Holsinger et al. 2002).

$\beta$-Catenin interacts directly with several RPTPs, including LAR (Kypta et al. 1996), $\mathrm{PTP} \zeta / \beta$ (Meng et al. 2000), РTPK (Fuchs et al. 1996) and PTP $\lambda$ (Cheng et al. 1997). All of these PTPs (except PTP $\lambda$ ) can dephosphorylate $\beta$-catenin and have been proposed to regulate cadherin/ $\beta$-catenin interactions. It is not clear, though, how most of these biochemical events are actually regulated in the cell. In the case of $\mathrm{PTP} \zeta / \beta$, its ligand

\footnotetext{
Figure 2 PTP involvement with integrin and cadherin signalling. This schematic shows some of the documented binding partners and substrates of PTPs, at (A) sites of focal adhesions and (B) sites of cadherin binding. Dephosphorylation steps are depicted by red lines and tyrosine kinase reactions are shown by green arrows. Black lines indicate pathways that are stimulated. Grey arrows indicate the binding of extracellular ligands where known. All PTPs are shown in purple. In (B), cadherin and PTP $\mu / \lambda / \kappa$ each have homophilic binding partners, binding in trans from another cell. Note that all of the above interactions have been documented in at least one study, but their relative physiological importance is not yet known in every case. Some of these interactions may be competitive or cell specific and may not occur concurrently. See text for further details. SFKs, src family kinases; ECM, extracellular matrix.
} 


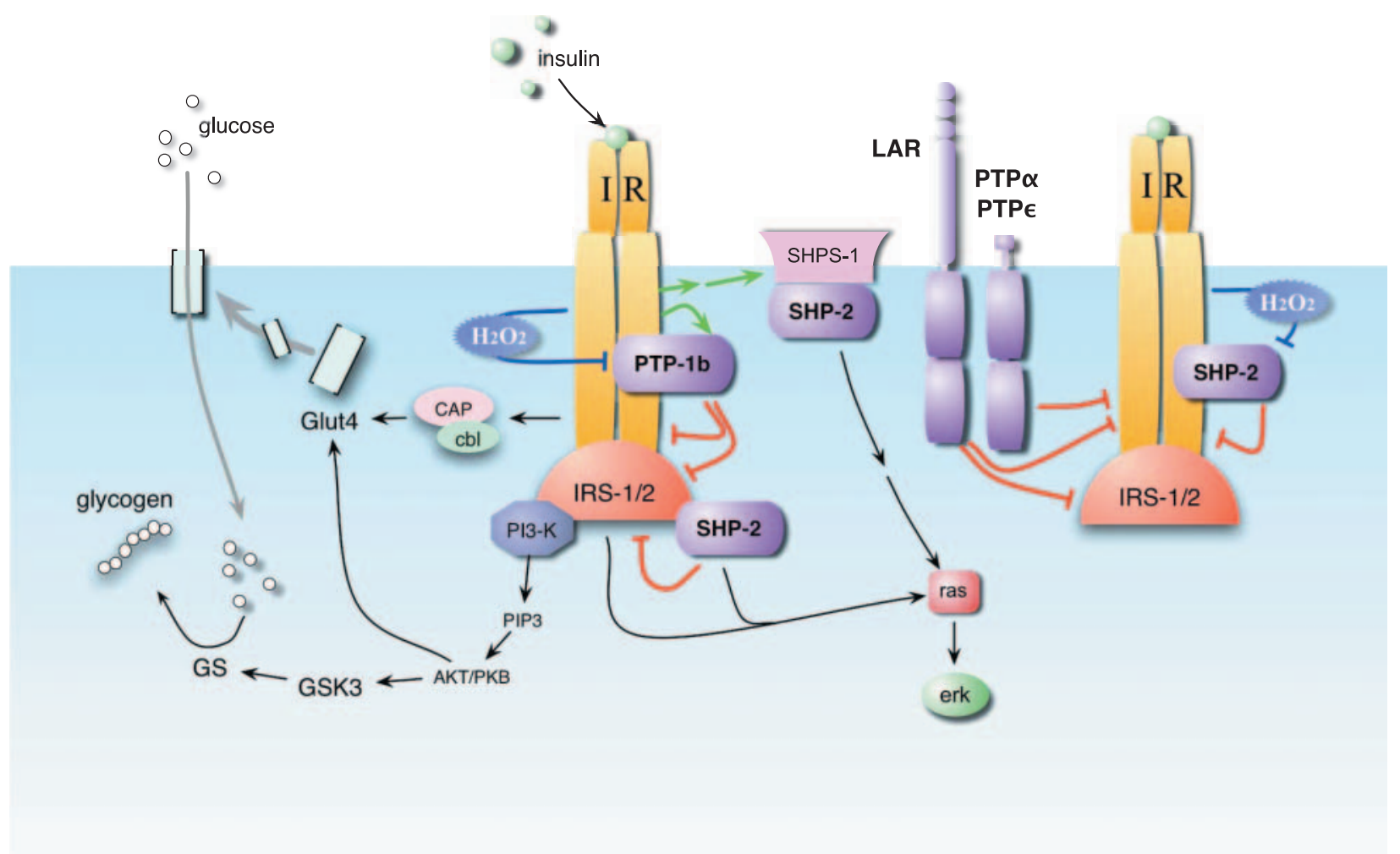

Figure 3 PTPs and insulin signalling. This diagram depicts the documented interactions between PTPs and components of the insulin signalling pathway. On the left of the diagram are some of the major pathways stimulated by the insulin receptor (IR) tyrosine kinase, leading to activation of glycogen synthase (GS) and movement of the glucose transporter Glut4 to the plasma membrane. PTP enzymes are shown in purple and dephosphorylation events are shown by red lines. Phosphorylation by tyrosine kinases is shown by green arrows; black lines indicate further pathways that are stimulated. Inactivation of PTPs by peroxide, which is produced following IR stimulation, is shown in blue. Note that all of the above interactions have been documented in at least one study, but their relative physiological importance is not yet known in every case. Some of these interactions may be competitive or cell specific and may not occur concurrently. See text for further details.

pleiotrophin can inactivate the RPTP and this results in increased $\beta$-catenin phosphorylation (Meng et al. 2000). Although it is evident that PTPs can strongly influence the dynamics of cell-cell adhesion, we have much yet to learn. For example, if cadherin $/ \beta$-catenin interactions are regulated by the PTPs describe above, then why do we see so little perturbation of epithelial tissues in animals lacking their genes? The lack of such phenotypes may indicate a high level of biochemical redundancy in the control of $\beta$-catenin phosphorylation. Whether several PTPs must actively co-operate to regulate $\beta$-catenin phosphorylation, or whether there are key PTPs in specific cell types, remains to be determined.

In cultured tumour cells, overexpression of LAR causes reduced $\beta$-catenin phosphorylation, stabilisation of adherens junctions and loss of tumour formation, indicating that this RPTP could have a powerful controlling effect over epithelial integrity in vivo (Müller et al. 1999). In this context, it will be most interesting to see if LAR or any other PTPs are developmentally controlled in order to influence events such as epithelial-mesenchymal transitions.

\section{Insulin signalling}

One field in which PTP action has been well studied is that of insulin signalling (Cheng et al. 2002a, AsanteAppiah \& Kennedy 2003) (Fig. 3). Given the increasing concern surrounding diabetes and obesity, particularly with insulin-resistant forms, it is not surprising that the molecular regulation of the insulin receptor (IR; an RTK), has come under scrutiny. There is particularly keen interest in understanding how PTPs might impinge on the signalling of the IR and whether PTPs are relevant therapeutic targets. Here, a number of PTPs have been implicated in recent years (Fig. 3), although their status as IR regulators is still controversial in most cases. 
LAR LAR expression is increased in fat tissue of clinically obese humans (Ahmad et al. 1995) and increased co-immunoprecipitation of LAR with the IR occurs after insulin treatment (Ahmad \& Goldstein 1997). Furthermore, overexpression of LAR suppresses insulin action (Li et al. 1996, Zhang et al. 1996) and antisense knock-down of LAR enhances and prolongs insulin signalling in McA-RH7777 hepatoma cells (Kulas et al. 1995, 1996, Mooney et al. 1997). These data are consistent with LAR being a direct, negative regulator of the IR. Engineered overexpression of LAR in mouse skeletal muscle suppresses IR signalling, causing insulin resistance possibly through deactivation of the insulin receptor substrate IRS-2 (Zabolotny et al. 2001). In LAR-deficient mice, although there is increased insulin sensitivity at the resting state, there are also unexpected defects in glucose homeostasis after insulin treatment that are more consistent with insulin resistance (Ren et al. 1998). The case for LAR being a significant regulator of the IR therefore remains unresolved.

PTP $\alpha$ and PTPE Overexpression of PTP $\alpha$ in BHK-IR cells causes dephosphorylation of the IR and suppresses IR-mediated cell rounding (Lammers et al. 1997). The highly related PTPe enzyme has also been implicated as a potential IR phosphatase in one overexpression study in BHK cells (Andersen et al. 2001). Furthermore, in adipocytes, rat PTP $\alpha$ can decrease the transport of the insulin-responsive glucose transporter Glut4 after insulin stimulation (Cong et al. 1999). However, a case against PTP $\alpha$ being a physiological regulator of the IR comes from studies of 3T3-L1 cells, where antisense PTP $\alpha$ does not affect insulin-induced MAP kinase activation or DNA synthesis (Arnott et al. 1999), and from mice deficient for PTP $\alpha$, where there are no defects in glucose homeostasis yet reported (Ponniah et al. 1999, Su et al. 1999).

SHP-2 SHP-2 binds to the IR and to IRS-1 in yeast two-hybrid assays (Rocchi et al. 1996) and in transfected cells (Kharitonenkov et al. 1995), and IRS-1 is also likely to be a direct substrate (Hayashi et al. 2004). In another study, wild-type SHP-2 did not interact with the IR in yeast two-hybrids, whereas a phosphatase-dead mutant did (via tyrosine 1146 on the IR). This suggests that the IR is also a direct substrate (Rocchi et al. 1996). However, a further study suggests that IR is not a substrate, but instead indicates that SHP-2 may bind to the IR in order to recruit IRS-1 (Kharitonenkov et al. 1995).

Several studies conclude that SHP-2 does affect the insulin signalling process itself, but again there is a lack of consensus. Interference with SHP-2 activity can block insulin-stimulated mitosis in 3 T3 cells (Milarski \& Saltiel 1994) and block downstream activation of Ras (Noguchi et al. 1994). In contrast, mutated forms of IRS-1 that do not bind SHP-2 can facilitate effective insulin signalling in
32D cells and these IRS-1 forms are even hyperphosphorylated (Myers et al. 1998). SHP-2 also binds to IRS-3 (Ross et al. 1998) and IRS-4 (Escribano et al. 2003), so perhaps there is further degeneracy in the system. Another pathway through which SHP-2 may act in concert with the IR involves SHPS-1 (see also Fig. 2) (Takada et al. 1998). SHPS-1 is phosphorylated in response to IR stimulation, and recruits SHP-2. Overexpression of wildtype SHPS-1 in $\mathrm{CHO}$ cells enhances MAP kinase activation downstream of insulin stimulation, whereas mutated forms of SHPS-1 that cannot recruit SHP-2 show no enhancement (Takada et al. 1998). How SHPS-1/ SHP-2 interactions stimulate MAP kinase in this system remains to be determined.

Transgenic analyses of SHP-2 function have also proved equivocal. Homozygous null mice do not survive, whereas heterozygotes appear normal with respect to glucose homeostasis, and IR and IRS-1 phosphorylation (Arrandale et al. 1996). Nevertheless, ubiquitous expression of a dominant-negative form of SHP-2 causes significant insulin resistance and reduced IRS-1 phosphorylation (Maegawa et al. 1999). This latter study again supports the idea that SHP-2 plays a positive role in insulin signalling.

PTP1B PTP1B has drawn much recent attention as being a negative regulator of insulin action (Cheng et al. 2002a, Asante-Appiah \& Kennedy 2003). PTP1B associates with the IR after insulin treatment and several critical tyrosine residues in PTP1B become phosphorylated (Seely et al. 1996, Bandyopadhyay et al. 1997). Importantly, the IR is a substrate for PTP1B (Bandyopadhyay et al. 1997, Dadke et al. 2000, Salmeen et al. 2000) and there is evidence that IRS-1 is also (Goldstein et al. 2000). Homozygous loss of PTP1B has no gross effect on mouse development or viability. However, the mice have defects in glucose and insulin tolerance, they also remain sensitive to insulin (when on high fat diets) and they show increases in IR phosphorylation after insulin treatment (Elchebly et al. 1999, Klaman et al. 2000). However, most of these effects only occur in muscle and liver, suggesting that further PTPs might control insulin signalling in fat cells.

PTP1B is widely expressed and localises predominantly in the endoplasmic reticulum (Frangioni et al. 1992), although it does have a cleavable carboxy-terminal domain that allows release into the cytosol (Frangioni et al. 1993). It is not exactly clear, therefore, how PTP1B is getting access to the IR. Like some other RPTKs, the IR may become endocytosed and thereby gain access to endoplasmic reticulum-associated PTP1B (Cheng et al. 2002a, Haj et al. 2002). Lastly, it is worth noting that PTP1B has also been implicated in controlling obesity, through the regulation of leptin action (Cheng A. et al. 2002b, Zabolotny et al. 2002). Interested readers are encouraged to read further details reviewed by Asante-Appiah \& Kennedy (2003). 
Other PTPs The PTPs that act upon the IR may not be limited to those above. A study employing substratetrapping PTPs suggested that PTP $\gamma$, Sap- 1 and TC-PTP could bind specifically to phosphorylated IR 'baits' (Walchli et al. 2000). However, further tests showed that a wider range of wild-type PTPs could dephosphorylate an IR-derived target peptide (containing the principal PTP target tyrosines; PTPGMTRDIYETDYYRKGGKG). It is not clear, therefore, how these in vitro assays will relate to the substrate specificity or accessibility of these PTPs towards the IR in vivo.

It is clear that PTPs significantly influence the level of insulin signalling and these enzymes do represent potential, pharmacological targets in insulin-resistant diabetes. This field remains controversial, however, with strong evidence pointing to PTP1B being the major player, but with several other PTPs hovering in the wings. The field currently suffers from numerous apparently contradictory findings and the loss-of-function mouse strains have added to the uncertainty by sometimes failing to corroborate cell culture data. Tissue-specific action of certain PTPs, or the concerted actions of multiple PTPs, may both therefore serve to control IR phosphorylation levels in vivo. Developing any diabetes therapies based on PTP inhibition therefore remains a worthy goal, and a considerable challenge.

\section{Regulation of PTP action}

It is evident from the discussion above that molecular control of the PTPs themselves is still relatively poorly understood. Recent research, however, is beginning to provide much-needed insight and some key findings are discussed below.

\section{Phosphorylation and SH2 domains}

PTP enzymes can be phosphorylated on tyrosines, providing binding sites for $\mathrm{SH} 2$-containing proteins. SH2 domains are protein adaptor modules with specific affinity for phosphorylated tyrosine residues on proteins (Pawson et al. 2001, Pawson 2004). These domains act as docking devices, facilitating the formation of supramolecular signalling complexes (Pawson et al. 2001, Neel et al. 2003, Pawson 2004). One RPTP that attracts such SH2 domains is PTP $\alpha$. The tyrosine residue 789 in D2 of PTP $\alpha$ is constitutively phosphorylated and associates with the SH2 domain of Grb2 (Fig. 4) (Den Hertog \& Hunter 1996, Su et al. 1996). Upon PKC $\delta$ phosphorylation of PTP $\alpha$, Grb2 is exchanged for $\mathrm{pp} 60^{\mathrm{scc}}$, whose own $\mathrm{SH} 2$ domain now associates with tyr789 (Zheng et al. 2002, Brandt et al. 2003). Through a 'phosphotyrosine displacement' mechanism, the inhibitory C-terminal tyr527 of $\mathrm{pp} 60^{\mathrm{src}}$ is thus released and is then dephosphorylated by PTP $\alpha$, activating pp60 $0^{\text {src }}$ (Zheng et al. 2000, 2002). Concurrently, Grb2 is released from PTP $\alpha$ and becomes free to associate, via its SH3 domain, with SOS, leading to downstream signalling (Fig. 4) (Den Hertog \& Hunter 1996).

\section{Cleavage and differential localisation}

Many proteins are subject to post-translational proteolytic cleavage and PTPs are no exception. A number of RPTPs are cleaved by subtilisin-like proteases (Streuli et al. 1992, Jiang et al. 1993, SerraPages et al. 1994, Gebbink et al. 1995, Campan et al. 1996, Aicher et al. 1997) and this can ultimately result in ectodomain 'shedding', at least in cell culture. A role for shedding in vivo is currently conjectural, but it may be a mechanism to either terminate RPTP signalling, facilitate internalisation of catalytic domains, or to release ectodomains to compete for ligands. Intracellular cleavage also occurs. PTP $\varepsilon$, PTP $\alpha$ and PTP1B can be cleaved in a calpain-dependent manner, releasing their catalytic domains into the cytoplasm (Frangioni et al. 1993, Gil-Henn et al. 2001). This may prevent access of the PTPs to membrane-associated substrates, or provide access to novel substrates.

\section{Ligands for RPTPS}

Upon the discovery of receptor-like RPTPs with their highly conserved ectodomains, there was great interest in their potential to be regulated by extracellular ligands. Since that time there have been great difficulties in identifying the ligands for many RPTPs and, even more so, understanding their effects on RPTP activity. A number of RPTPs have homophilic binding properties, including the type IIb enzymes, as well as PTP $\delta$ and isoforms of LAR (Yang et al. 2003, for reviews see Beltran \& Bixby 2003, Johnson \& van Vactor 2003). Of those RPTPs with heterophilic binding properties, PTP $\zeta / \beta$ binds pleiotrophin and adhesion molecules (Beltran \& Bixby 2003), РTPб binds to heparan sulphate proteoglycans (Aricescu et al. 2002) and LAR binds the laminin/ nidogen complex (O'Grady et al. 1998). Of these RPTP interactions, only the interaction between pleiotrophin and $\mathrm{PTP} \zeta / \beta$ has so far been shown to have a clear effect on enzyme activity: pleiotrophin binding inhibits $\mathrm{PTP} \zeta / \beta$ and causes an increase in $\beta$-catenin phosphorylation (Meng et al. 2000).

Several major areas must therefore be clarified with respect to RPTP ligands. Why has it been so hard to identify heterotypic ligands for many RPTPs? Does this mean that some RPTPs do not have ligands? For example, work with CD45 suggests that the activity of this enzyme can be modulated through changes in protein isoform expression and the consequent changes in ectodomain glycosylation and dimerisation (Xu \& Weiss 2002). Understanding whether the trans interactions of RPTP ectodomains generally activate or inactivate the catalytic activity of RPTPs also remains a challenge for the field. 


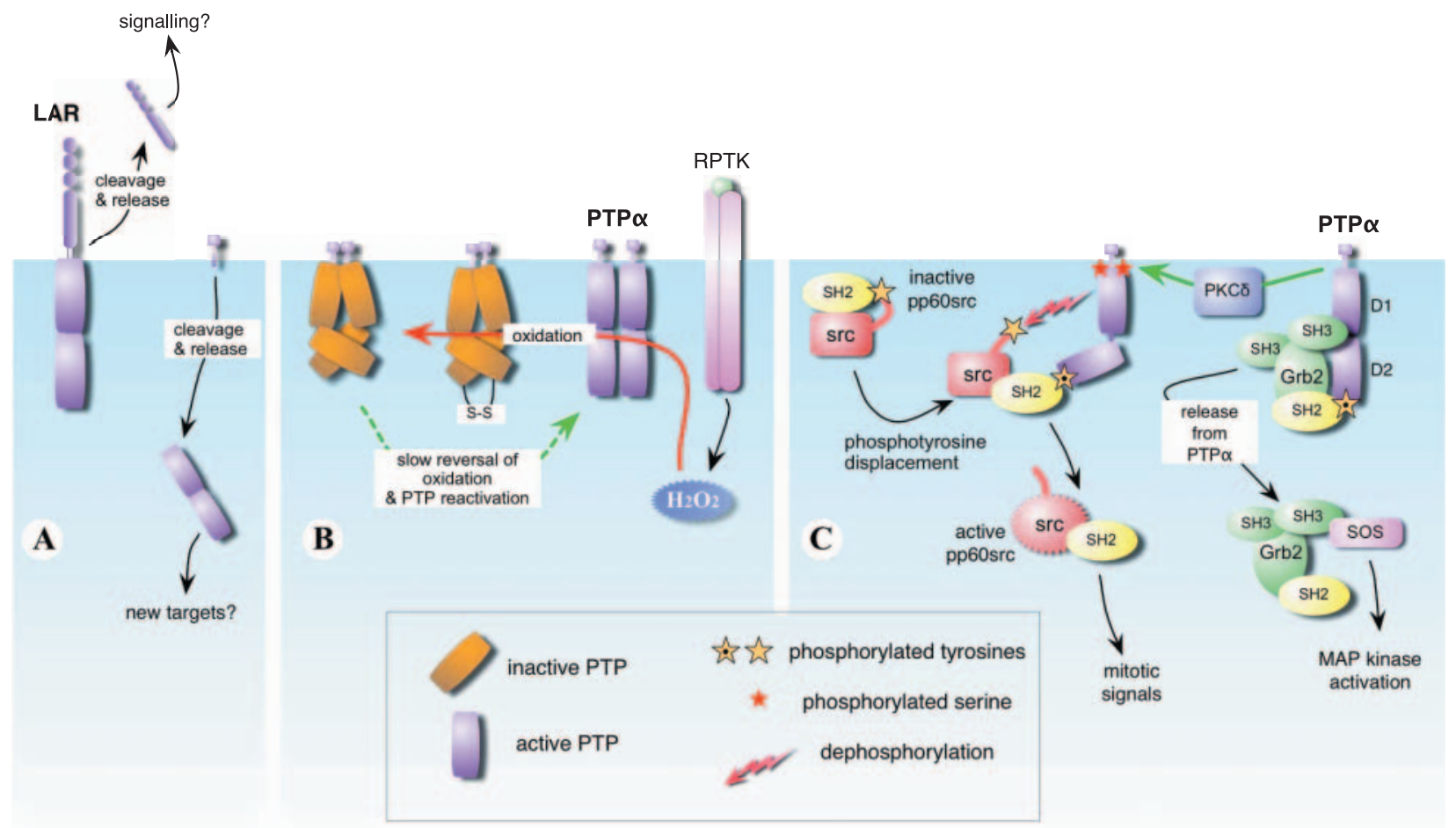

Figure 4 The regulation of PTP activity. This diagram shows three different ways in which RPTPs are regulated (A) by cleavage, (B) by oxidation and dimerisation and (C) by phosphorylation. The precise role of these events is still uncertain for many RPTPs. (A) Cleavage and extracellular shedding of ectodomains has been reported for several RPTPs (shown here for LAR). (B) Some RPTPs, including PTP $\alpha$ and CD45 are present as dimers in the membrane. Inactivation of dimers can occur through oxidation of D1/D2 catalytic sites and conformational changes. Oxidation is caused by peroxide that is released following growth factor receptor activation; this oxidation is reversible in the cell. (C) Phosphorylation of PTP $\alpha$ by PKC $\delta$ causes detachment of Grb2 followed by attachment of pp60 src, effectively through $\mathrm{SH} 2$ domain exchange. Binding of the $\mathrm{SH} 2$ domain of pp60 ${ }^{\mathrm{src}}$ to PTP $\alpha$ exposes phosphotyrosine 527 in pp60 ${ }^{\mathrm{src}}$ (yellow star), which is then dephosphorylated by PTP $\alpha$.

There remains the possibility that RPTPs require cis rather than trans interactions to promote intramembrane compartmentalisation into, for example, lipid rafts. Finally, cis interactions between ectodomains themselves may not necessarily require a ligand, but could still be essential in enforcing dimerisation and regulating enzyme activity.

\section{PTP dimerisation}

A well-known prerequisite for the activation of receptor PTKs is their dimerisation and autophosphorylation (Heldin 1995). In 1998, It was found that the catalytic domains of PTP $\alpha$ formed dimer-like structures when crystallised (Majeti et al. 1998, Wallace et al. 1998), and it was subsequently shown that the full-length protein dimerises in live cells (Jiang et al. 1999, 2000). Dimerisation in cis has also been demonstrated for CD45 (Takeda et al. 1992) and it could well be a common phenomenon for RPTPs in general. Suggestions as to how dimers might regulate RPTP signalling have been given. As with RPTKs (Heldin 1995), the rotational orientation of dimerised receptor PTP $\alpha$ has been shown to be critical for its full activation (Jiang et al. 1999). It was also found that an inhibitory peptide 'wedge' caused reciprocal blockade of the catalytic sites of the dimerised D1 domains, revealing a potential inactivation mechanism (Majeti et al. 1998, Wallace et al. 1998). However, although 'wedge' inhibition may occur with PTP $\alpha$ and CD45, it appears less feasible with LAR and PTP $\mu$ (Hoffmann et al. 1997, Nam et al. 1999), and therefore may not be a universal inhibitory mechanism. It is still likely, however, that RPTPs can have a dimerised, rotational state that engenders catalytic inactivity with or without involvement of a wedge. One further, outstanding question is whether the dimerisation process itself is generally constitutive, or whether it requires the presence of a ligand.

\section{PTP oxidation}

The catalytic site cysteines of PTPs have an ionisation constant $(\mathrm{PKa})$ of between 5 and 6 . They are therefore usually deprotonated and susceptible to oxidative attack, which inactivates the catalytic site at least temporarily (Fig. 4) (Xu et al. 2002). Oxidation of PTPs could be an elegant 
mechanism by which RPTKs briefly impede local PTP activity and thereby prolong PTK signals (Xu et al. 2002). Indeed, the activation of growth factor receptors does produce a local burst of peroxide capable of oxidising PTPs (Bae et al. 1997, Lee et al. 1998, Meng et al. 2002, 2004). In the case of the IR, PTP1B may inhibit insulin signalling, but the IR itself may in turn inhibit (albeit temporarily) PTP1B through local oxidant production (Mahadev et al. 2001). For most RPTPs, the obvious candidate for oxidative attack is the catalytically active D1 domain. However, studies of PTP $\alpha$ show that D2 is the initial, selective target, and its oxidation causes conformational shifts in the catalytic domains that result in prolonged enzyme inactivation (Blanchetot et al. 2002, Persson et al. 2004) (Fig. 4). Finally, a recent study suggests that PTP $\alpha$ can briefly form disulphide-linked dimers when treated with peroxide and that the D2 active site cysteines are again critical for this event (van der Wijk et al. 2004). The relevance of this event to other native RPTPs remains to be addressed.

There is therefore justifiable excitement that a universal regulatory mechanism may now have been uncovered for PTPs, although many key questions remain. For example, how precisely do PTKs stimulate peroxide production and how localised is it in the cell? In addition, the percentage of a given PTP that is inactivated varies widely between studies. Although much of this may arise from the varied experimental protocols, we have yet to define the necessary levels of PTP inactivation that would be required for the sustained activation of RPTK signalling. This is not a trivial undertaking, but it has far-reaching consequences for our understanding of PTP regulation.

\section{Conclusions and future prospects}

The road to discovery with the PTP family has been long and arduous, but its box of secrets is finally being prised open, revealing true surprises. We see that PTPs are closely involved in many levels of cell biological control. Furthermore, the enzymes can be controlled and modulated in diverse and novel ways, including through oxidation, dimerisation, cleavage, differential localisation, use of differential mRNA splicing, or combinations of these. There also appears to be cellular and developmental tolerance to their individual loss of function in many cases, suggesting that highly conserved redundancy or degeneracy is in place in order to maintain control of PTK signalling pathways. The discovery of oxidative regulation in particular has profound implications and may trigger novel pharmacological approaches for PTP inhibition or activation. Other exciting challenges include understanding the structure and function of RPTP ectodomains, defining more precisely the substrate specificities of PTPs, and finally discovering how these extremely active enzymes are harnessed by cells to act with apparent specificity in so many signalling pathways. As our knowledge thus increases, the ultimate goal of applying it to a therapeutic setting, tackling human diseases with underlying dysregulation of phosphotyrosine signalling, will come closer to fruition.

\section{Acknowledgements}

I would like to thank Radu Aricescu for helpful comments on the manuscript. All figures were designed using Omnigraffle Pro software. The author declares that there is no conflict of interest that would prejudice the impartiality of this scientific work.

\section{References}

Ahmad F \& Goldstein BJ 1997 Functional association between the insulin receptor and the transmembrane protein-tyrosine phosphatase LAR in intact cells. Journal of Biological Chemistry 272 448-457.

Ahmad F, Considine RV \& Goldstein BJ 1995 Increased abundance of the receptor-type protein-tyrosine phosphatase LAR accounts for the elevated insulin receptor dephosphorylating activity in adipose tissue of obese human subjects. Journal of Clinical Investigation 95 2806-2812.

Aicher B, Lerch MM, Muller T, Schilling J \& Ullrich A 1997 Cellular redistribution of protein tyrosine phosphatases LAR and PTPsigma by inducible proteolytic processing. Journal of Cell Biology 138 681-696.

Alonso A, Sasin J, Bottini N, Friedberg I, Osterman A, Godzik A, Hunter T, Dixon J \& Mustelin T 2004 Protein tyrosine phosphatases in the human genome. Cell 117 699-711.

Andersen JN, Elson A, Lammers R, Romer J, Clausen JT, Moller KB \& Moller NP 2001 Comparative study of protein tyrosine phosphatase-epsilon isoforms: membrane localization confers specificity in cellular signalling. Biochemical Journal 354 581-590.

Angers-Loustau A, Cote JF \& Tremblay ML 1999a Roles of protein tyrosine phosphatases in cell migration and adhesion. Biochemistry and Cell Biology 77 493-505.

Angers-Loustau A, Cote JF, Charest A, Dowbenko D, Spencer S, Lasky LA \& Tremblay ML $1999 b$ Protein tyrosine phosphatase-PEST regulates focal adhesion disassembly, migration, and cytokinesis in fibroblasts. Journal of Cell Biology 144 1019-1031.

Aricescu AR, McKinnell IW, Halfter W \& Stoker AW 2002 Heparan sulfate proteoglycans are ligands for receptor protein tyrosine phosphatase sigma. Molecular and Cellular Biology 22 1881-1892.

Arnott CH, Sale EM, Miller J \& Sale GJ 1999 Use of an antisense strategy to dissect the signaling role of protein-tyrosine phosphatase alpha. Journal of Biological Chemistry 274 26105-26112.

Arrandale JM, Gore Willse A, Rocks S, Ren JM, Zhu J, Davis A, Livingston JN \& Rabin DU 1996 Insulin signaling in mice expressing reduced levels of Syp. Journal of Biological Chemistry 271 21353-21358.

Arregui CO, Balsamo J \& Lilien J 1998 Impaired integrin-mediated adhesion and signaling in fibroblasts expressing a dominant-negative mutant PTP1B. Journal of Cell Biology 143 861-873.

Asante-Appiah E \& Kennedy BP 2003 Protein tyrosine phosphatases: the quest for negative regulators of insulin action. American Journal of Physiology-Endocrinology and Metabolism 284 E663-E670.

Bae YS, Kang SW, Seo MS, Baines IC, Tekle E, Chock PB \& Rhee SG 1997 Epidermal growth factor (EGF)-induced generation of hydrogen peroxide. Role in EGF receptor-mediated tyrosine phosphorylation. Journal of Biological Chemistry 272 217-221. 
Balsamo J, Leung T, Ernst H, Zanin MK, Hoffman S \& Lilien J 1996 Regulated binding of PTP1B-like phosphatase to N-cadherin: control of cadherin-mediated adhesion by dephosphorylation of beta-catenin. Journal of Cell Biology 134 801-813.

Balsamo J, Arregui C, Leung T \& Lilien J 1998 The nonreceptor protein tyrosine phosphatase PTP1B binds to the cytoplasmic domain of $\mathrm{N}$-cadherin and regulates the cadherin-actin linkage. Journal of Cell Biology 143 523-532.

Bandyopadhyay D, Kusari A, Kenner KA, Liu F, Chernoff J, Gustafson TA \& Kusari J 1997 Protein-tyrosine phosphatase 1B complexes with the insulin receptor in vivo and is tyrosinephosphorylated in the presence of insulin. Journal of Biological Chemistry 272 1639-1645.

Beltran PJ \& Bixby JL 2003 Receptor protein tyrosine phosphatases as mediators of cellular adhesion. Frontiers in Bioscience 8 D87-D99.

Blanchetot C, Tertoolen LG \& den Hertog J 2002 Regulation of receptor protein-tyrosine phosphatase alpha by oxidative stress. EMBO Journal 21 493-503.

Brady Kalnay SM, Rimm DL \& Tonks NK 1995 Receptor protein tyrosine phosphatase PTPmu associates with cadherins and catenins in vivo. Journal of Cell Biology 130 977-986.

Brady-Kalnay SM, Mourton T, Nixon JP, Pietz GE, Kinch M, Chen H, Brackenbury R, Rimm DL, Del Vecchio RL \& Tonks NK 1998 Dynamic interaction of PTPmu with multiple cadherins in vivo. Journal of Cell Biology 141 287-296.

Brandt DT, Goerke A, Heuer M, Gimona M, Leitges M, Kremmer E, Lammers R, Haller H \& Mischak H 2003 Protein kinase C delta induces Src kinase activity via activation of the protein tyrosine phsophatase PTPalpha. Journal of Biological Chemistry 278 34073-34078.

Buist A, Blanchetot C, Tertoolen LG \& den Hertog J 2000 Identification of $\mathrm{p} 130 \mathrm{Cas}$ as an in vivo substrate of receptor protein-tyrosine phosphatase alpha. Journal of Biological Chemistry 275 20754-20761.

Campan M, Yoshizumi M, Seidah NG, Lee ME, Bianchi C \& Haber E 1996 Increased proteolytic processing of protein tyrosine phosphatase $\mathrm{mu}$ in confluent vascular endothelial cells: the role of PC5, a member of the subtilisin family. Biochemistry 35 3797-3802.

Charest A, Wagner J, Kwan M \& Tremblay ML 1997 Coupling of the murine protein tyrosine phosphatase PEST to the epidermal growth factor (EGF) receptor through a Src homology 3 (SH3) domain-mediated association with Grb2. Oncogene 14 1643-1651.

Cheng A, Bal GS, Kennedy BP \& Tremblay ML 2001 Attenuation of adhesion-dependent signaling and cell spreading in transformed fibroblasts lacking protein tyrosine phosphatase-1B. Journal of Biological Chemistry 276 25848-25855.

Cheng A, Dube N, Gu F \& Tremblay ML 2002a Coordinated action of protein tyrosine phosphatases in insulin signal transduction. European Journal of Biochemistry 269 1050-1059.

Cheng A, Uetani N, Simoncic PD, Chaubey VP, Lee-Loy A, McGlade CJ, Kennedy BP \& Tremblay ML $2002 b$ Attenuation of leptin action and regulation of obesity by protein tyrosine phosphatase 1B. Developmental Cell 2 497-503.

Cheng J, Wu K, Armanini M, O’Rourke N, Dowbenko D \& Lasky LA 1997 A novel protein-tyrosine phosphatase related to the homotypically adhering kappa and mu receptors. Journal of Biological Chemistry 272 7264-7277.

Cong LN, Chen H, Li Y, Lin CH, Sap J \& Quon MJ 1999 Overexpression of protein tyrosine phosphatase-alpha (PTP-alpha) but not PTP-kappa inhibits translocation of GLUT4 in rat adipose cells. Biochemical and Biophysical Research Communications 255 200-207.

Dadke S, Kusari J \& Chernoff J 2000 Down-regulation of insulin signaling by protein-tyrosine phosphatase $1 \mathrm{~B}$ is mediated by an N-terminal binding region. Journal of Biological Chemistry 275 23642-23647.

Daniel JM \& Reynolds AB 1997 Tyrosine phosphorylation and cadherin/catenin function. Bioessays 19 883-891.
Davidson D \& Veillette A 2001 PTP-PEST, a scaffold protein tyrosine phosphatase, negatively regulates lymphocyte activation by targeting a unique set of substrates. EMBO Journal 20 3414-3426.

Davidson D, Cloutier JF, Gregorieff A \& Veillette A 1997 Inhibitory tyrosine protein kinase p50 csk is associated with protein-tyrosine phosphatase PTP-PEST in hemopoietic and non-hemopoietic cells Journal of Biological Chemistry 272 23455-23462.

Debant A, Serra Pages C, Seipel K, O’Brien S, Tang M, Park SH \& Streuli M 1996 The multidomain protein Trio binds the LAR transmembrane tyrosine phosphatase, contains a protein kinase domain, and has separate rac-specific and rho-specific guanine nucleotide exchange factor domains. PNAS 93 5466-5471.

Den Hertog J \& Hunter T 1996 Tight association of GRB2 with receptor protein-tyrosine phosphatase alpha is mediated by the SH2 and C-terminal SH3 domains. EMBO Journal 15 3016-3027.

Elchebly M, Payette P, Michaliszyn E, Cromlish W, Collins S, Loy AL, Normandin D, Cheng A, Himms-Hagen J, Chan CC et al. 1999 Increased insulin sensitivity and obesity resistance in mice lacking the protein tyrosine phosphatase-1B gene. Science $\mathbf{2 8 3}$ 1544-1548.

Ensslen-Craig SE \& Brady-Kalnay SM 2004 Receptor protein tyrosine phosphatases regulate neural development and axon guidance. Developmental Biology 275 12-22.

Escribano O, Fernandez-Moreno MD, Zueco JA, Menor C, Fueyo J, Ropero RM, Diaz-Laviada I, Roman ID \& Guijarro LG 2003 Insulin receptor substrate-4 signaling in quiescent rat hepatocytes and in regenerating rat liver. Hepatology 37 1461-1469.

Espanel X, Walchli S, Gobert RP, El Alama M, Curchod ML, Gullu-Isler N \& van Huijsduijnen RH 2001 Pulling stringsH below the surface: hormone receptor signaling through inhibition of protein tyrosine phosphatases. Endocrine 15 19-28.

Fauman EB \& Saper MA 1996 Structure and function of the protein tyrosine phosphatases. Trends in Biochemical Science 21 413-417.

Feng GS 1999 Shp-2 tyrosine phosphatase: signaling one cell or many. Experimental Cell Research 253 47-54.

Frangioni JV, Beahm PH, Shifrin V, Jost CA \& Neel BG 1992 The nontransmembrane tyrosine phosphatase PTP-1B localizes to the endoplasmic reticulum via its 35 amino acid C-terminal sequence. Cell 68 545-560.

Frangioni JV, Oda A, Smith M, Salzman EW \& Neel BG 1993 Calpain-catalyzed cleavage and subcellular relocation of protein phosphotyrosine phosphatase $1 \mathrm{~B}$ (PTP-1B) in human platelets. EMBO Journal 12 4843-4856.

Fuchs M, Mueller T, Lerch MM \& Ullrich A 1996 Association of human protein-tyrosine phosphatase kappa with members of the armadillo family. Journal of Biological Chemistry 271 16712-16719.

Garton AJ \& Tonks NK 1994 PTP-PEST: a protein tyrosine phosphatase regulated by serine phosphorylation. EMBO Journal 13 3763-3771.

Garton AJ \& Tonks NK 1999 Regulation of fibroblast motility by the protein tyrosine phosphatase PTP-PEST. Journal of Biological Chemistry 274 3811-3818.

Garton AJ, Burnham MR, Bouton AH \& Tonks NK 1997 Association of PTP-PEST with the SH3 domain of p130 cas; a novel mechanism of protein tyrosine phosphatase substrate recognition. Oncogene 15 877-885.

Gebbink MF, Zondag GC, Koningstein GM, Feiken E, Wubbolts RW \& Moolenaar WH 1995 Cell surface expression of receptor protein tyrosine phosphatase RPTP mu is regulated by cell-cell contact. Journal of Cell Biology 131 251-260.

Gil-Henn H, Volohonsky G \& Elson A 2001 Regulation of protein-tyrosine phosphatases alpha and epsilon by calpain-mediated proteolytic cleavage. Journal of Biological Chemistry 276 31772-31779.

Goldstein BJ, Bittner-Kowalczyk A, White MF \& Harbeck M 2000 Tyrosine dephosphorylation and deactivation of insulin receptor 
substrate-1 by protein-tyrosine phosphatase 1B. Possible facilitation by the formation of a ternary complex with the Grb2 adaptor protein. Journal of Biological Chemistry 275 4283-4289.

Grossmann J 2002 Molecular mechanisms of 'detachment-induced apoptosis-Anoikis'. Apoptosis 7 247-260.

Gu J, Tamura M \& Yamada KM 1998 Tumor suppressor PTEN inhibits integrin- and growth factor-mediated mitogen-activated protein (MAP) kinase signaling pathways. Journal of Cell Biology 143 $1375-1383$.

Haj FG, Verveer PJ, Squire A, Neel BG \& Bastiaens PI 2002 Imaging sites of receptor dephosphorylation by PTP1B on the surface of the endoplasmic reticulum. Science 295 1708-1711.

Harder KW, Moller NP, Peacock JW \& Jirik FR 1998 Protein-tyrosine phosphatase alpha regulates Src family kinases and alters cell-substratum adhesion. Journal of Biological Chemistry 273 31890-31900.

Hassid A, Huang S \& Yao J 1999 Role of PTP-1B in aortic smooth muscle cell motility and tyrosine phosphorylation of focal adhesion proteins. American Journal of Physiology-Heart and Circulatory Physiology 277 H192-H198.

Hayashi K, Shibata K, Morita T, Iwasaki K, Watanabe M \& Sobue K 2004 Insulin receptor substrate-1/SHP-2 interaction, a phenotype-dependent switching machinery of IGF-I signaling in vascular smooth muscle cells. Journal of Biological Chemistry 279 40807-40818.

Heldin CH 1995 Dimerization of cell surface receptors in signal transduction. Cell 80 213-223.

Hirohashi S 1998 Inactivation of the E-cadherin-mediated cell adhesion system in human cancers. American Journal of Pathology 153 333-339.

Hoffmann KM, Tonks NK \& Barford D 1997 The crystal structure of domain 1 of receptor protein-tyrosine phosphatase mu. Journal of Biological Chemistry 272 27505-27508.

Holsinger LJ, Ward K, Duffield B, Zachwieja J \& Jallal B 2002 The transmembrane receptor protein tyrosine phosphatase DEP1 interacts with p120(ctn). Oncogene 21 7067-7076.

Inagaki K, Noguchi T, Matozaki T, Horikawa T, Fukunaga K, Tsuda M, Ichihashi M \& Kasuga M 2000 Roles for the protein tyrosine phosphatase SHP-2 in cytoskeletal organization, cell adhesion and cell migration revealed by overexpression of a dominant negative mutant. Oncogene 19 75-84.

Jiang G, den Hertog J, Su J, Noel J, Sap J \& Hunter T 1999 Dimerization inhibits the activity of receptor-like protein-tyrosine phosphatase-alpha. Nature 401 606-610.

Jiang G, den Hertog J \& Hunter T 2000 Receptor-like protein tyrosine phosphatase alpha homodimerizes on the cell surface. Molecular and Cellular Biology 20 5917-5929.

Jiang YP, Wang H, D'Eustachio P, Musacchio JM, Schlessinger J \& Sap J 1993 Cloning and characterization of R-PTP-kappa, a new member of the receptor protein tyrosine phosphatase family with a proteolytically cleaved cellular adhesion molecule-like extracellular region. Molecular and Cellular Biology 13 2942-2951.

Johnson KG \& Van Vactor D 2003 Receptor protein tyrosine phosphatases in nervous system development. Physiological Reviews 83 1-24.

Keilhack H, Hellman U, van Hengel J, van Roy F, Godovac-Zimmermann J \& Bohmer FD 2000 The protein-tyrosine phosphatase SHP-1 binds to and dephosphorylates p120 catenin. Journal of Biological Chemistry 275 26376-26384.

Kharitonenkov A, Schnekenburger J, Chen Z, Knyazev P, Ali S, Zwick E, White M \& Ullrich A 1995 Adapter function of protein-tyrosine phosphatase $1 \mathrm{D}$ in insulin receptor/insulin receptor substrate-1 interaction. Journal of Biological Chemistry 270 29189-29193.

Klaman LD, Boss O, Peroni OD, Kim JK, Martino JL, Zabolotny JM, Moghal N, Lubkin M, Kim YB, Sharpe AH et al. 2000 Increased energy expenditure, decreased adiposity, and tissue-specific insulin sensitivity in protein-tyrosine phosphatase $1 \mathrm{~B}$-deficient mice. Molecular and Cellular Biology 20 5479-5489.

Kowalczyk AP \& Reynolds AB 2004 Protecting your tail: regulation of cadherin degradation by 120 -catenin. Current Opinion in Cell Biology 16 522-527.

Kulas DT, Zhang WR, Goldstein BJ, Furlanetto RW \& Mooney RA 1995 Insulin receptor signaling is augmented by antisense inhibition of the protein tyrosine phosphatase LAR. Journal of Biological Chemistry 270 2435-2438.

Kulas DT, Goldstein BJ \& Mooney RA 1996 The transmembrane protein-tyrosine phosphatase LAR modulates signaling by multiple receptor tyrosine kinases. Journal of Biological Chemistry 271 748-754.

Kypta RM, Su H \& Reichardt LF 1996 Association between a transmembrane protein tyrosine phosphatase and the cadherin-catenin complex. Journal of Cell Biology 134 1519-1529.

Lammers R, Moller NP \& Ullrich A 1997 The transmembrane protein tyrosine phosphatase alpha dephosphorylates the insulin receptor in intact cells. FEBS Letters 404 37-40.

Larsen M, Tremblay ML \& Yamada KM 2003 Phosphatases in cell-matrix adhesion and migration. Nature Reviews Molecular Cell Biology 4 700-711.

Lee SR, Kwon KS, Kim SR \& Rhee SG 1998 Reversible inactivation of protein-tyrosine phosphatase 1B in A431 cells stimulated with epidermal growth factor. Journal of Biological Chemistry 273 15366-15372.

Li PM, Zhang WR \& Goldstein BJ 1996 Suppression of insulin receptor activation by overexpression of the protein-tyrosine phosphatase LAR in hepatoma cells. Cell Signal 8 467-473.

Lilien J, Balsamo J, Arregui C \& Xu G 2002 Turn-off, drop-out: functional state switching of cadherins. Developmental Dynamics 224 $18-29$.

Liliental J, Moon SY, Lesche R, Mamillapalli R, Li D, Zheng Y, Sun H \& Wu H 2000 Genetic deletion of the Pten tumor suppressor gene promotes cell motility by activation of Rac1 and Cdc42 GTPases. Current Biology 10 401-404.

Liu F, Sells MA \& Chernoff J 1998 Protein tyrosine phosphatase 1B negatively regulates integrin signaling. Current Biology 8 173-176.

Maegawa H, Hasegawa M, Sugai S, Obata T, Ugi S, Morino K, Egawa K, Fujita T, Sakamoto T, Nishio Y et al. 1999 Expression of a dominant negative SHP-2 in transgenic mice induces insulin resistance. Journal of Biological Chemistry 274 30236-30243.

Mahadev K, Zilbering A, Zhu L \& Goldstein BJ 2001 Insulin-stimulated hydrogen peroxide reversibly inhibits protein-tyrosine phosphatase $1 \mathrm{~b}$ in vivo and enhances the early insulin action cascade. Journal of Biological Chemistry 276 21938-21942.

Majeti R, Bilwes AM, Noel JP, Hunter T \& Weiss A 1998 Dimerization-induced inhibition of receptor protein tyrosine phosphatase function through an inhibitory wedge. Science $\mathbf{2 7 9}$ 88-91.

Manes S, Mira E, Gomez-Mouton C, Zhao ZJ, Lacalle RA \& Martinez AC 1999 Concerted activity of tyrosine phosphatase SHP-2 and focal adhesion kinase in regulation of cell motility. Molecular and Cellular Biology 19 3125-3135.

Meng K, Rodriguez-Pena A, Dimitrov T, Chen W, Yamin M, Noda M \& Deuel TF 2000 Pleiotrophin signals increased tyrosine phosphorylation of beta-catenin through inactivation of the intrinsic catalytic activity of the receptor-type protein tyrosine phosphatase beta/zeta. PNAS 97 2603-2608.

Meng TC, Fukada T \& Tonks NK 2002 Reversible oxidation and inactivation of protein tyrosine phosphatases in vivo. Molecular Cell 9 387-399.

Meng TC, Buckley DA, Galic S, Tiganis T \& Tonks NK 2004 Regulation of insulin signaling through reversible oxidation of the protein tyrosine phosphatases TC45 and PTP1B. Journal of Biological Chemistry $27937716-37725$. 
Miao H, Burnett E, Kinch M, Simon E \& Wang B 2000 Activation of EphA2 kinase suppresses integrin function and causes focal-adhesion-kinase dephosphorylation. Nature Cell Biology 2 62-69.

Milarski KL \& Saltiel AR 1994 Expression of catalytically inactive Syp phosphatase in 3T3 cells blocks stimulation of mitogen-activated protein kinase by insulin. Journal of Biological Chemistry 269 21239-21243.

Miranti CK \& Brugge JS 2002 Sensing the environment: a historical perspective on integrin signal transduction. Nature Cell Biology 4 E83-E90.

Mooney RA, Kulas DT, Bleyle LA \& Novak JS 1997 The protein tyrosine phosphatase LAR has a major impact on insulin receptor dephosphorylation. Biochemical and Biophysical Research Communications 235 709-712.

Müller T, Choidas A, Reichmann E \& Ullrich A 1999 Phosphorylation and free pool of beta-catenin are regulated by tyrosine kinases and tyrosine phosphatases during epithelial cell migration. Journal of Biological Chemistry 274 10173-10183.

Myers MG Jr, Mendez R, Shi P, Pierce JH, Rhoads R \& White MF 1998 The COOH-terminal tyrosine phosphorylation sites on IRS-1 bind SHP-2 and negatively regulate insulin signaling. Journal of Biological Chemistry 273 26908-26914.

Nakagawa S \& Takeichi M 1998 Neural crest emigration from the neural tube depends on regulated cadherin expression. Development 125 2963-2971.

Nam HJ, Poy F, Krueger NX, Saito H \& Frederick CA 1999 Crystal structure of the tandem phosphatase domains of RPTP LAR. Cell $97449-457$.

Neel BG, Gu H \& Pao L 2003 The 'Shp'ing news': SH2 domain-containing tyrosine phosphatases in cell signaling. Trends in Biochemical Science 28 284-293.

Noguchi T, Matozaki T, Horita K, Fujioka Y \& Kasuga M 1994 Role of SH-PTP2, a protein-tyrosine phosphatase with Src homology 2 domains, in insulin-stimulated Ras activation. Molecular and Cellular Biology 14 6674-6682.

O'Grady P, Thai TC \& Saito H 1998 The laminin-nidogen complex is a ligand for a specific splice isoform of the transmembrane protein tyrosine phosphatase LAR. Journal of Cell Biology 141 1675-1684.

Oh ES, Gu H, Saxton TM, Timms JF, Hausdorff S, Frevert EU, Kahn BB, Pawson T, Neel BG \& Thomas SM 1999 Regulation of early events in integrin signaling by protein tyrosine phosphatase SHP-2. Molecular and Cellular Biology 19 3205-3215.

O'Neill GM, Fashena SJ \& Golemis EA 2000 Integrin signalling: a new Cas $(\mathrm{t})$ of characters enters the stage. Trends in Cell Biology 10 111-119.

Ozawa M \& Ohkubo T 2001 Tyrosine phosphorylation of p120(ctn) in $\mathrm{v}-\mathrm{Src}$ transfected $\mathrm{L}$ cells depends on its association with E-cadherin and reduces adhesion activity. Journal of Cell Science $\mathbf{1 1 4}$ 503-512.

Parsons JT 2003 Focal adhesion kinase: the first ten years. Journal of Cell Science 116 1409-1416.

Pathre P, Arregui C, Wampler T, Kue I, Leung T, Lilien J \& Balsamo J 2001 PTP1B regulates neurite extension mediated by cell-cell and cell-matrix adhesion molecules. Journal of Neuroscience Research 63 143-150.

Paul S \& Lombroso PJ 2003 Receptor and nonreceptor protein tyrosine phosphatases in the nervous system. Cellular and Molecular Life Sciences 60 2465-2482.

Pawson T 2004 Specificity in signal transduction: from phosphotyrosine-SH2 domain interactions to complex cellular systems. Cell 116 191-203.

Pawson T, Gish GD \& Nash P 2001 SH2 domains, interaction modules and cellular wiring. Trends in Cell Biology 11 504-511.

Peifer M \& Yap AS 2003 Traffic control: p120-catenin acts as a gatekeeper to control the fate of classical cadherins in mammalian cells. Journal of Cellular Biology 163 437-440.
Persson C, Sjoblom T, Groen A, Kappert K, Engstrom U, Hellman U, Heldin CH, den Hertog J \& Ostman A 2004 Preferential oxidation of the second phosphatase domain of receptor-like PTP-alpha revealed by an antibody against oxidized protein tyrosine phosphatases. PNAS 101 1886-1891.

Pixley FJ, Lee PS, Dominguez MG, Einstein DB \& Stanley ER 1995 A heteromorphic protein-tyrosine phosphatase, PTP phi, is regulated by CSF-1 in macrophages. Journal of Biological Chemistry $27027339-27347$.

Pixley FJ, Lee PS, Condeelis JS \& Stanley ER 2001 Protein tyrosine phosphatase phi regulates paxillin tyrosine phosphorylation and mediates colony-stimulating factor 1 -induced morphological changes in macrophages. Molecular and Cellular Biology 21 1795-1809.

Poliakov A, Cotrina M \& Wilkinson DG 2004 Diverse roles of eph receptors and ephrins in the regulation of cell migration and tissue assembly. Developmental Cell 7 465-480.

Ponniah S, Wang DZ, Lim KL \& Pallen CJ 1999 Targeted disruption of the tyrosine phosphatase PTPalpha leads to constitutive downregulation of the kinases Src and Fyn. Current Biology 9 $535-538$.

Ramponi G \& Stefani M 1997 Structure and function of the low Mr phosphotyrosine protein phosphatases. Biochimica et Biophysica Acta 1341 137-156.

Ren JM, Li PM, Zhang WR, Sweet LJ, Cline G, Shulman GI, Livingston JN \& Goldstein BJ 1998 Transgenic mice deficient in the LAR protein-tyrosine phosphatase exhibit profound defects in glucose homeostasis (in process citation). Diabetes 47 493-497.

Rocchi S, Tartare-Deckert S, Sawka-Verhelle D, Gamha A \& van Obberghen E 1996 Interaction of SH2-containing protein tyrosine phosphatase 2 with the insulin receptor and the insulin-like growth factor-I receptor: studies of the domains involved using the yeast two-hybrid system. Endocrinology 137 4944-4952.

Ross SA, Lienhard GE \& Lavan BE 1998 Association of insulin receptor substrate 3 with SH2 domain-containing proteins in rat adipocytes. Biochemica et Biophysica Research Communications 247 487-492.

Roura S, Miravet S, Piedra J, Garcia de Herreros A \& Dunach M 1999 Regulation of E-cadherin/catenin association by tyrosine phosphorylation. Journal of Biological Chemistry 274 36734-36740.

Salmeen A, Andersen JN, Myers MP, Tonks NK \& Barford D 2000 Molecular basis for the dephosphorylation of the activation segment of the insulin receptor by protein tyrosine phosphatase 1B. Molecular Cell 6 1401-1412.

Schaller MD, Hildebrand JD, Shannon JD, Fox JW, Vines RR \& Parsons JT 1994 Autophosphorylation of the focal adhesion kinase, pp125(FAK), directs SH2- dependent binding of pp60(src). Molecular and Cellular Biology 14 1680-1688.

Schwartz MA 2001 Integrin signaling revisited. Trends in Cell Biology 11 466-470.

Schwarzbauer JE 1997 Cell migration: may the force be with you. Current Biology 7 R292-R294.

Schwartzberg PL 1998 The many faces of Src: multiple functions of a prototypical tyrosine kinase. Oncogene 17 1463-1468.

Seely BL, Staubs PA, Reichart DR, Berhanu P, Milarski KL, Saltiel AR, Kusari J \& Olefsky JM 1996 Protein tyrosine phosphatase $1 \mathrm{~B}$ interacts with the activated insulin receptor. Diabetes $\mathbf{4 5}$ 1379-1385.

Serra-Pages C, Saito H \& Streuli M 1994 Mutational analysis of proprotein processing, subunit association, and shedding of the LAR transmembrane protein tyrosine phosphatase. Journal of Biological Chemistry $26923632-23641$.

Serra-Pages C, Kedersha NL, Fazikas L, Medley Q, Debant A \& Streuli M 1995 The LAR transmembrane protein tyrosine phosphatase and a coiled-coil LAR-interacting protein co-localize at focal adhesions. EMBO Journal 14 2827-2838. 
Serra-Pages C, Medley QG, Tang M, Hart A \& Streuli M 1998 Liprins, a family of LAR transmembrane protein-tyrosine phosphatase-interacting proteins. Journal of Biological Chemistry 273 15611-15620.

Shen Y, Schneider G, Cloutier JF, Veillette A \& Schaller MD 1998 Direct association of protein-tyrosine phosphatase PTP-PEST with paxillin. Journal of Biological Chemistry 273 6474-6481.

Stoker AW 2001 Receptor tyrosine phosphatases in axon growth and guidance. Current Opinions in Neurobiology 11 95-102.

Streuli M, Kreuger NX, Hall LR, Schlossman SF \& Saito H 1988 A new member of the immunoglobulin superfamily that has a cytoplasmic region homologous to the leukocyte common antigen. Journal of Experimental Medicine 168 1523-1530.

Streuli M, Krueger NX, Ariniello PD, Tang M, Munro JM, Blattler WA, Adler DA, Disteche CM \& Saito H 1992 Expression of the receptor-linked protein tyrosine phosphatase LAR: proteolytic cleavage and shedding of the CAM-like extracellular region. EMBO Journal 11 897-907.

Su J, Yang LT \& Sap J 1996 Association between receptor protein-tyrosine phosphatase RPTPalpha and the Grb2 adaptor. Dual Src homology (SH) 2/SH3 domain requirement and functional consequences. Journal of Biological Chemistry 271 28086-28096.

Su J, Muranjan M \& Sap J 1999 Receptor protein tyrosine phosphatase alpha activates Src-family kinases and controls integrin-mediated responses in fibroblasts. Current Biology 9 505-511.

Sun H, Lesche R, Li DM, Liliental J, Zhang H, Gao J, Gavrilova N, Mueller B, Liu X \& Wu H 1999 PTEN modulates cell cycle progression and cell survival by regulating phosphatidylinositol 3,4,5,-trisphosphate and Akt/protein kinase B signaling pathway. PNAS 96 6199-6204.

Takada T, Matozaki T, Takeda H, Fukunaga K, Noguchi T, Fujioka Y, Okazaki I, Tsuda M, Yamao T, Ochi F et al. 1998 Roles of the complex formation of SHPS-1 with SHP-2 in insulin-stimulated mitogen-activated protein kinase activation. Journal of Biological Chemistry 273 9234-9242.

Takeda A, Wu JJ \& Maizel AL 1992 Evidence for monomeric and dimeric forms of CD45 associated with a $30-\mathrm{kDa}$ phosphorylated protein. Journal of Biological Chemistry 267 16651-16659.

Tamura M, Gu J, Matsumoto K, Aota S, Parsons R \& Yamada KM 1998 Inhibition of cell migration, spreading, and focal adhesions by tumor suppressor PTEN. Science 280 1614-1617.

Tamura M, Gu J, Takino T \& Yamada KM 1999a Tumor suppressor PTEN inhibition of cell invasion, migration, and growth: differential involvement of focal adhesion kinase and p130 Cas. Cancer Research 59 442-449.

Tamura M, Gu J, Tran H \& Yamada KM 1999b PTEN gene and integrin signaling in cancer. Journal of the National Cancer Institute $\mathbf{9 1}$ 1820-1828.

Tamura M, Gu J, Danen EH, Takino T, Miyamoto S \& Yamada KM 1999 c PTEN interactions with focal adhesion kinase and suppression of the extracellular matrix-dependent phosphatidylinositol 3-kinase/Akt cell survival pathway. Journal of Biological Chemistry 274 20693-20703.

Tsuda M, Matozaki T, Fukunaga K, Fujioka Y, Imamoto A, Noguchi T, Takada T, Yamao T, Takeda H, Ochi F et al. 1998 Integrin-mediated tyrosine phosphorylation of SHPS-1 and its association with SHP-2. Roles of Fak and Src family kinases. Journal of Biological Chemistry 273 13223-13229.

Walchli S, Curchod ML, Gobert RP, Arkinstall S \& Hooft van Huijsduijnen R 2000 Identification of tyrosine phosphatases that dephosphorylate the insulin receptor. A brute force approach based on 'substrate-trapping' mutants. Journal of Biological Chemistry 275 9792-9796.
Wallace MJ, Fladd C, Batt J \& Rotin D 1998 The second catalytic domain of protein tyrosine phosphatase delta (PTP delta) binds to and inhibits the first catalytic domain of PTP sigma (in process citation). Molecular and Cellular Biology 18 2608-2616.

Wei L, Yang Y, Zhang X \& Yu Q 2002 Anchorage-independent phosphorylation of $\mathrm{p} 130$ (Cas) protects lung adenocarcinoma cells from anoikis. Journal of Cellular Biochemistry 87 439-449.

Wei L, Yang Y, Zhang X \& Yu Q 2004 Cleavage of p130 Cas in anoikis. Journal of Cellular Biochemistry 91 325-335.

Weng LP, Yuan J \& Yu Q 1998 Overexpression of the transmembrane tyrosine phosphatase LAR activates the caspase pathway and induces apoptosis (in process citation). Current Biology 8 247-256.

Weng LP, Wang X \& Yu Q 1999 Transmembrane tyrosine phosphatase LAR induces apoptosis by dephosphorylating and destabilizing p130 Cas. Genes to Cells 4 185-196.

van der Wijk T, Overvoorde J \& den Hertog J 2004 $\mathrm{H}-{ }_{2} \mathrm{O}_{2}$-induced intermolecular disulfide bond formation between receptor protein-tyrosine phosphatases. Journal of Biological Chemistry 279 44355-44361.

Xu D, Rovira I \& Finkel T 2002 Oxidants painting the cysteine chapel: redox regulation of PTPs. Developmental Cell 2 251-252.

Xu G, Craig AW, Greer P, Miller M, Anastasiadis PZ, Lilien J \& Balsamo J 2004 Continuous association of cadherin with beta-catenin requires the non-receptor tyrosine-kinase Fer. Journal of Cell Science 117 3207-3219.

Xu Z \& Weiss A 2002 Negative regulation of CD45 by differential homodimerization of the alternatively spliced isoforms. Nature Immunology 3 764-771.

Yamada KM \& Araki M 2001 Tumor suppressor PTEN: modulator of cell signaling, growth, migration and apoptosis. Journal of Cell Science $1142375-2382$.

Yang T, Bernabeu R, Xie Y, Zhang JS, Massa SM, Rempel HC \& Longo FM 2003 Leukocyte antigen-related protein tyrosine phosphatase receptor: a small ectodomain isoform functions as a homophilic ligand and promotes neurite outgrowth. Journal of Neuroscience 23 3353-3363.

Yu DH, Qu CK, Henegariu O, Lu X \& Feng GS 1998 Protein-tyrosine phosphatase Shp-2 regulates cell spreading, migration, and focal adhesion. Journal of Biological Chemistry 273 21125-21131.

Zabolotny JM, Kim YB, Peroni OD, Kim JK, Pani MA, Boss O, Klaman LD, Kamatkar S, Shulman GI, Kahn BB et al. 2001 Overexpression of the LAR (leukocyte antigen-related) protein-tyrosine phosphatase in muscle causes insulin resistance. PNAS 98 5187-5192.

Zabolotny JM, Bence-Hanulec KK, Stricker-Krongrad A, Haj F, Wang Y, Minokoshi Y, Kim YB, Elmquist JK, Tartaglia LA, Kahn $\mathrm{BB}$ et al. 2002 PTP1B regulates leptin signal transduction in vivo. Developmental Cell 2 489-495.

Zamir E \& Geiger B 2001 Molecular complexity and dynamics of cell-matrix adhesions. Journal of Cell Science 114 3583-3590.

Zeng L, Si X, Yu WP, Le HT, Ng KP, Teng RM, Ryan K, Wang DZ, Ponniah S \& Pallen CJ 2003 PTP alpha regulates integrin-stimulated FAK autophosphorylation and cytoskeletal rearrangement in cell spreading and migration. Journal of Cell Biology 160 137-146.

Zhang SQ, Yang W, Kontaridis MI, Bivona TG, Wen G, Araki T, Luo J, Thompson JA, Schraven BL, Philips MR et al. 2004 Shp2 regulates SRC family kinase activity and Ras/Erk activation by controlling Csk recruitment. Molecular Cell 13 341-355.

Zhang WR, Li PM, Oswald MA \& Goldstein BJ 1996 Modulation of insulin signal transduction by eutopic overexpression of the receptor-type protein-tyrosine phosphatase LAR. Molecular Endocrinology 10 575-584. 
Zheng XM, Resnick RJ \& Shalloway D 2000 A phosphotyrosine displacement mechanism for activation of Src by PTPalpha. EMBO Journal 19 964-978.

Zheng XM, Resnick RJ \& Shalloway D 2002 Mitotic activation of PTPalpha and regulation of its Src-mediated transforming activity by its sites of PKC phosphorylation. Journal of Biological Chemistry 277 21922-21929.

Zondag GC, Moolenaar WH \& Gebbink MF 1996 Lack of association between receptor protein tyrosine phosphatase RPTP mu and cadherins. Journal of Cell Biology 134 1513-1517.
Zondag GC, Reynolds AB \& Moolenaar WH 2000 Receptor protein-tyrosine phosphatase RPTPmu binds to and dephosphorylates the catenin p120(ctn). Journal of Biological Chemistry 275 11264-11269.

Received 11 March 2004

Accepted 6 January 2005

Made available online as an

Accepted Preprint 1 February 2005 